Ekonomi terhadap Gaya Hidup Seseorang

\title{
Status Ekonomi Berdampak Terhadap Gaya Hidup Seseorang
}

\author{
Checi Arum Septiani, Muhammad Ali Sodik \\ IIK STRADA INDONESIA \\ arumcheci@gmail.com , alisodik2012@gmail.com
}

\begin{abstract}
Abstrak
Gaya hidup atau Lifestyle adalah gambaran tingkah laku, pola dan cara hidup yang ditunjukkan bagaimana aktivitas seseorang, minat dan ketertarikan serta apa yang mereka pikirkan tentang diri mereka sendiri sehingga membedakan statusnya dari orang lain dan lingkungan melalui lambang-lambang sosial yang mereka miliki. Gaya hidup berkaitan erat dengan perkembangan zaman dan teknologi. Gaya hidup menjadi upaya untuk membuat diri menjadi eksis dengan cara tertentu dan berbeda dari kelompok lain. Berdasarkan pengalaman sendiri yang diperbandingkan dengan realitas sosial, individu memilih rangkaian tindakan dan penampilan mana yang menurutnya sesuai dan mana yang tidak sesuai untuk ditampilkan dengan ruang sosial.
\end{abstract}

\section{Latar Belakang}

Status sosial ekonomi merupakan suatu tingkatan atau kedudukan seseorang di dalam masyarakat yang dilihat dari tingkat pendidikan, tingkat pekerjaan, tingkat penghasilan dan kekayaan serta pengeluarannya. Pada dasarnya gaya hidup seseorang menggambarkan jiwa seseorang dan perilaku seseorang . Ekonomi merupakan salah satu faktor yang dapat mempengaruhi gaya hidup seseorang. Ekonomi yang baik maupun buruk dapat memengaruhi gaya hidup sesorang secara drastis. Contohnya, ketika seseorang yang dulunya hidup sederhana dan ketika sukses dia menjadi gemar foya - foya atau yang pada saat ini biasa kita sebut dengan gayahidup headon. Sebaliknya, jika biasanya ada seseorang yang kaya lalu mengalami masalah berat pada ekonominya biasanya orang tersebut akan mengalami depresi dan akan mempengaruhi mental orang tersebut. Pada saat ini, saya akan mengkaji mengenai keselarasa n status ekonomi terhadap gaya hidup seseorang.

\section{Kasus / Masalah}

Pada 2018 lalu, peristiwa yang dialami Adelina Sau, buruh migran asal Nusa Tenggara Timur (NTT) menjadi sebuah kisah pilu bagi Indonesia. Ia dikabarkan 
meninggal karena malnutrisi dan mendapat perlakuan keji dari majikannya di Malaysia.

Kasus Adelina ini tak hanya menunjukkan buruknya tata kelola ketenagakerjaan di Indonesia, namun pada hakekatnya menjadi gambaran tentang parahnya ketimpangan di negara ini. Bila ditelusuri, Adelina adalah warga yang menemui kesulitan dalam meningkatkan kesejahteraan hidupnya, sehingga terpaksa keluar dari daerahnya untuk mengadu nasib di negara lain yang lebih maju.

\section{Tinjauan Pustaka}

Status ekonomi adalah kedudukan atau posisi seseorang dalam masyarakat, status social ekonomi adalah gambaran tentang keadaan seseorang atau masyarakat yang ditinjau dari segi social ekonomi, gambaran itu seperti tingkat pendidikan, pendapatan, dan sebagainya. Status ekonomi kemungkinan besar pembentuk gaya hidup keluarga (Soetjiningsingsih,2004).

1). Klasifikasi status ekonomi (Supariasa, 2002: 178) :

a. Pekerjaan (pekerjaan utama misalnya pekerjaan pertanian dan pekerjaan tambahan misalnya pekerjaan musiman).

b. Pendapatan keluarga (gaji, indusri rumah tangga, pertanian pangan, non pangan, utang).

c. Kekayaan yang telihat seperti tanah, jumlah ternak, perahu, mesin jahit, kendaraan, radio, TV, dll.

d. Pengeluaran atau anggaran (penegluaran untuk makan, pakaian, menyewa, minya tau bahan bakar, listrik, pendidikan, transportasi, rekreasi, hadiah/persembahan).

e. Harga makanan yang tergantung pada pasar dan variasi musiman.

2). Menurut Friedman 2004 faktor yang mempengaruhi ekonomi seseorang yaitu :

a. Pendidikan

Pendidikan berarti bimbingan yang diberikan oleh seseorang terhadap perkembangan orang lain menuju kearah suatu citacita tertentu. Makin tinggi tingkat pendidikan seseorang maka makin mudah memperoleh perkerjaan, sehingga makin banyak pula hasil yang diperoleh. Sebaliknya pendidikan yang kurang akan menghambat sikap seseorang terhadap nilai yang baru dikenal.

b. Perkerjaan

Perkerjaan

adalah symbol status seseorang dalam masyarakat. Perkerjaan adalah jembatan untuk memperoleh uang dalam memenuhi kebutuhan hidup dan untuk mendapatkan pelayanan kesehatan yang diinginkan.

c. Keadaan ekonomi 
Kondisi ekonomi yang rendah tidak dapat mendorong seseorang untuk memenuhi kebutuhan hidupnya.

d. Pendapatan

Pendapatan adalah hasil yang diperoleh dari kerja atau usaha yang telah dilakukan. Pendapatan akan mempengaruhi gaya hidup seseorang. Orang atau keluarga yang mempunyai ststus ekonomi atau pendapatan lebih tinggi akan mempratikan gaya hidup yang mewah misalnya lebih konsumtif karna mampu membeli semua yang dibutuhkan bila dibandingkan dengan status ekonomi yang ke bawah.

Gaya hidup merupakan kata lain dari Life Style, yang didefinisikan sebagai bagian dari kebutuhan sekunder manusia yang bisa berubah sesuai zaman atau keinginan seseorang untuk berubah gaya hidupnya. Gaya hidup dapat diketahui dari cara berpakaian, kebiasaan, dan lain sebagainya. Gaya hidup ini berhubungan dengan perkembangan zaman dan juga teknologi. Gaya hidup adalah usaha seseorang untuk membuat dirinya eksis dengan

cara tertetntu dan tidak sama dari kelompok lain. Menurut KBBI (Kamus Besar Bahasa Indonesi) 2008 gaya hidup adalah pola tingkah laku seharihari segolongan manusia dalam masyarakat.
Gaya hidup berkembang karena ada kebutuhan, tuntutan dan penguatan, adalah mahzab behavioristik yang menyatakan bahwa suatu perilaku akan diulangi bila perilaku tersebut membawa kepuasan atau kenikmatan dan tidak ada hukuman yang menyertainya. Gaya hidup menurut Kotler (2009) adalah pola hidup seseorang di dunia yang diekspresikan dalam aktivitas, minat, dan opininya. Gaya hidup menggambarkan "keseluruhan diri seseorang" dalam berinteraksi dengan lingkungannya. Menurut Assael (1984), gaya hidup adalah "A mode of living that is identified by how people spend their time (activities), what they consider important in their environment (interest), and what they think of themselvesand the world around them (opinions)". Secara umum dapat diartikan sebagai suatu gaya hidup yang 10 dikenali dengan bagaimana orang menghabiskan waktunya (aktivitas), apa yang penting orang pertimbangkan pada lingkungan (minat), dan apa yang orang pikirkan tentang diri sendiri dan dunia di sekitar (opini). Sedangkan menurut Minor dan Mowen (2000), gaya hidup menunjukkan bagaimana seseorang hidup, bagaimana membelanjakan uangnya, dan bagaimana mengalokasikan waktu. Gaya hidup mencerminkan keseluruhan pribadi yang berinteraksi dengan lingkungan. Dari pengertian di atas maka dapat disimpulkan 
bahwa gaya hidup merupakan suatu pola hidup seseorang tentang bagaimana mereka menghabiskan waktu mereka, apa yang mereka anggap paling penting bagi diri mereka dalam kehidupan sehari-hari dan bagaimana pandangan mereka tentang diri mereka ataupun tentang dunia luar sekitar mereka.

\section{Pembahasan}

\section{A. Pengertian Status Ekonomi}

Tingkat ekonomi seseorang berhubungan erat dengan berbagai masalah kesehatan Orang dengan tingkat ekonomi rendah akan lebih berkosentrasi terhadap pemenuhan kebutuhan dasar yang menunjang kehidupannya dan kehidupan keluarganya. Sebaliknya orang dengan tingkat ekonomi tinggi akan mempunyaikesempatan lebih besar dalam menempuh

pendidikan dimana orang dengan tingkat ekonomi tinggi akan lebih mudah menerima informasi sehingga makin banyak pula pengetahuan yang dimiliki sehingga makin banyak pula pengetahuan yang dimiliki sehingga akan memperhatikan kesehatan diri dan keluarga.

Status sosial ekonomi adalah tinggi rendahnya prestise yang dimiliki seseorang berdasarkan kedudukan yang dipegangnya dalam suatu masyarakat berdasarkan pada pekerjaan untuk memenuhi kebutuhannya atau keadaan yang menggambarkan posisi atau kedudukan suatu keluarga masyarakat berdasarkan kepemilikan materi. Status sosial ekonomi seseorang dapat didasarkan pada beberapa unsur kepentingan manusia dalam kehidupannya, status dalam kehidupan masyarakat, yaitu status pekerjaan, status dalam sistem kekerabatan, status jabatan dan status agama yang dianut.

B. Pengertian Gaya Hidup

Gaya hidup (lifestyle) adalah bagian dari kebutuhan sekunder manusia yang bisa berubah sesuai zaman atau keinginan seseorang untuk berubah gaya hidupnya. Gaya hidup dapat diketahui dari cara berpakaian, kebiasaan, dan lain sebagainya. Dan juga, gaya hidup dapat dinilai relatif bergantung dari penilaian orang lain.

Pengertian lain dargi gaya hidup yaitu gambaran perbuatan, pola dan cara hidup yang ditunjukkan bagaimana kegiatan seseorang, minat dan ketertarikan dan juga apa yang mereka pikirkan 
tentang diri mereka sendiri menjadikan perbedaan statusnya dari orang lain dan lingkungan melalui lambang sosial yang mereka miliki.

Gaya hidup juga diartikan sebagai seni yang dibudidayakan masingmasing orang. Gaya hidup ini berhubungan dengan perkembangan zaman dan juga teknologi. Gaya hidup adalah usaha seseraogn untuk membuat dirinya eksis dengan cara tertetntu dan tidak sama dari kelompok lain.

Gaya Hidup adalah bagian dari kebutuhan sekunder manusia yang bisa berubah bergantung zaman atau keinginan seseorang untuk mengubah gaya hidupnya. Istilah gaya hidup pada awalnya dibuat oleh psikolog Austria, Alfred Adler dan Ferdinand the Bull, pada tahun 1929.

\section{Kesimpulan}

Status ekonomi berpengaruh dengan gaya hidup seseorang. Gaya hidup seseorang merupakan kebiasaan kita dalam memenuhi kebutuhan hidup. Jika seseorang berpenghasilan yang tinggi maka, keadaan tersebut akan mendorong individu untuk bergaya hidup yang tinggi. Sebaliknya, jika seseorang berpenghasilan atau berstatus ekonomi rendah maka, gaya hidup yang diterapkan rendah pula.

\section{Daftar Pustaka}

Spengetahuan. 2018. Pengertian Gaya Hidup, Jenis, Indikator, Faktor Yang Mempengaruhi. https://www.seputarpenge tahuan.co.id/2018/06/pengertian-gayahidup-jenis-jenis-indikator-faktor-yangmempengaruhi.html . 25 Januari 2021 (16.33)

Daniel, Joseph Robert. 2019. Gaya hidup konsumtif akibat majunya perekonomian Indonesia semakin menyisihkan orang miskin. https://theconversation.com/ gaya-hidup-konsumtif-akibat-majunyaperekonomian-indonesia-semakinmenyisihkan-orang-miskin-109334 25 Januari 2021 (14.49)

Riadi, Muchlisin. 2018. Pengertian, Jenis, Indikator dan Faktor yang Mempengaruhi Gaya Hidup. https://www.kajianpustaka.com/2018 103/pengertian-jenis-indikator-dan-faktoryang-mempengaruhi-gaya-hidup.html . 25 Januari 2021 (16.38)

\section{Dasar Status}

Studyofhealth23. 2015. Konsep

Ekonomi. http://studyofhealth23.blogspot.co m/2015/04/konsep-dasar-status-

ekonomi.html\#: :text=Status\%20ekonomi\% 20adalah\%20kedudukan\%20atau,pendidika n\%2C\%20pendapatan\%2C\%20dan\%20seba gainya. 25 Januari 2021 (16.41)

Wikipedia. 2020. Gaya Hidup. https://id.wikipedia.org/wiki/Gaya_hidup . 25 Januari 2021 (17.51)

Attoriq, S., \& Sodik, M. A. (2018). Pencegahan Dan Pengendalian Infeksi Terkait Pelayanan Kesehatan Di Lahan Praktik. 
Tule, A. R., Siyoto, S., Dwianngimawati, M. S., \& Sodik, M. A. (2018). The Analysis Factors Affecting Interest In Medication Of Receipt Help Aid Bpjs Participant In Balowerti Public Health Center Kediri City. Journal of Global Research in Publich Health, 3(1), 68-75.

Hidajaturrokhmah, N. Y., Nurikasari, M., Retnaningtyas, E., Siwi, R. P. Y., Sari, N., \& Sodik, M. A. (2018). Effectiveness of health education using audio visual with lectures and poster with lectures of changes in behavior selection of snacks. Indian Journal of Physiotherapy and Occupational Therapy-An International Journal, 12(4), 220-224.

Sodik, M. A., Astikasari, N. D., Fazrin, I., Chusnatayaini, A., \& Peristiowati, Y. (2018). Dental health child with retardation mental and parents behavior. Indian Journal of Physiotherapy and Occupational Therapy-An International Journal, 12(4), 278-282.

Sodik, M. A., \& Salam, D. M. (2020). Analysis Of Android-Based Online Message Gateway Towards The Use Of Plastic Bags. STRADA Jurnal Ilmiah Kesehatan, 9(2), 1657-1664.

Sodik, M. A., \& Nzilibili, S. M. M. (2017). The Role Of Health Promotion And Family Support With Attitude Of Couples Childbearing Age In Following Family Planning Program In Health. Journal of Global Research in Public Health, 2(2), 82-89.

Siyoto, S., Dwianggimawati, M. S., Sari, D. K., Mufida, R. T., \& Sodik, M. A. (2018). The Effect of Pornography Accessity to Influence Sexual Behavior. Indian Journal of Public Health Research \& Development, 9(12).

Sodik, M. A., Yudhana, A., \& Dwianggimawati, M. S. (2018). Nutritional status and anemia in islamic boarding school adolescent in Kediri City East Java Indonesia. Indonesian Journal of Nutritional Epidemiology and Reproductive, 1(3), 172-176.

Al Annas, S. N. N., Indasah, I., Yudhana, A., \& Sodik, M. A. (2018). Analysis of Using Basic Material and Process on Organoleptic Result of Tempe Chips in Ngantru Trenggalek. Indonesian Journal of Nutritional Epidemiology and Reproductive, 1(1), 46-55.

Sari, N., Yudhana, A., Wahyuni, C., Rusmawati, A., \& Sodik, M. A. (2018). Family support as a determinant safety riding student behavior in SMKN 2 Kediri. Indian Journal of Physiotherapy and Occupational Therapy-An International Journal, 12(4), 230-234. 